\title{
The role of labour market integration, language proficiency and inter-ethnic contacts in shaping life satisfaction among immigrants in the Netherlands
}

\author{
Iuliia E. Pletneva \\ Institute for Socio-Political Studies under the Russian Academy of Sciences \\ 6 Fotievoy St., bldg. 1, Moscow, 119333, Russian Federation
}

\begin{abstract}
Studies show relatively low life satisfaction among immigrants and ethnic minorities. At the same time, it was found that subjective well-being plays an important role in the process of social integration of immigrants. This study contributes to the existing literature by exploring the meditative role of integration in the labor market and inter-ethnic contacts in the relationship between language proficiency and life satisfaction among the first and second generation of Turkish and Moroccan immigrants in the Netherlands. Based on data from the Netherlands Longitudinal Lifecourse Study (NELLS), an analysis was performed using structural equation modeling. The results showed that despite the fact that language acquisition does not have a direct effect on increasing life satisfaction among immigrants, it does have a positive effect through increasing labor integration and contacts with members of the ethnic majority.
\end{abstract}

Keywords: migration; life satisfaction; socio-economic integration; language proficiency; interethnic contacts

\section{Introduction}

The large-scale immigration of Turkish and Moroccans workers began in the early 1960s and was caused, on the one hand, by the high population growth and mass unemployment in Turkey and Morocco, and on the other hand, by the labour shortage in Northwestern Europe. The Dutch government entered into a 'recruitment agreement' with Turkey in 1964 and with Morocco in 1969. Thereafter, the number of Turkish and Moroccan workers in the Netherlands increased rapidly. The oil crisis of the 1970s caused serious problems for the Dutch economy thus the unemployment rate increased dramatically. As a result of this economic crisis, the Dutch government decided to stop labour migration in 1973. However, the number of Turkish and Moroccan migrants continued to rise as a result of the introduction of the law on family reunification (1974). This law, that was adopted with the aid of churches, non-governmental organizations and

(C) Pletneva Iu.E., 2019

(c) () This work is licensed under a Creative Commons Attribution 4.0 International License https://creativecommons.org/licenses/by/4.0/ 
sympathetic academic activists, enabled the families left behind by many former guest labourers to move to the Netherlands. From that moment onwards, many women and children, especially of Moroccan or Turkish origin, began to arrive in the Netherlands. Now Turks and Moroccans have become two largest immigrant groups in the country.

Life satisfaction has been studied for many years from different perspectives across countries and social classes. Hong, Bianca and Bollington (1993) define life satisfaction as "an individual's personal judgment of well-being and quality of life based on his or her own chosen criteria" (p. 547). The most common approach was developed by Diener (1984) who argues that satisfaction with life should be studied in general with life as a whole instead of considering it across specific areas. Thus, Diener, Emmons, Larsen, and Griffin (1985) introduced the Satisfaction With Life Scale (SWLS) based on conclusion that life satisfaction is a latent factor which can be estimated by five highly correlated items. This approach has been tested in hundreds of studies and showed a good validity of assessment of an individual's general sense of satisfaction with life (Arrindell et al., 1999; Sachs, 2003; Böhnke, 2008).

While a lot of researches were addressed to a problem of life satisfaction it has been done to much less extent in immigrants' context. Although the number of studies is quite limited, researchers have found relatively low life satisfaction among immigrants and ethnic minority groups. In study conducted among 1207 women and 1326 men aged between 18 and 64 years Fugl-Meyer et al. (2002) found that being first-generation immigrants had lower level of satisfaction with life as a whole than the Swedish-raised respondents considering gender as a control variable. It was also revealed in study of Verkuyten (1987) that in the Netherlands adolescents with minority status based on ethnicity reported lower level of happiness than native Dutch adolescents of the same age.

Many studies were focused on determinants of individual's life satisfaction. Bohnke (2008) found that on the country level life satisfaction can be predicted to a large extent by taking into consideration the economic performance, the social security level, and the political culture in a country. In addition, life satisfaction was found to be associated with a range of individual background characteristics. Analyzing data from World Values Survey (WVS) (Inglehart et al., 2000) Helliwell (2003) found the evidence that education might increase life satisfaction through mediating role of social relationships and higher earnings. Bonini (2008) in a cross-national study reported that $81 \%$ of the variation in mean life satisfaction is explained by individual attributes such as gender, age, marital status, income and education.

Language proficiency is one of the key factors to successful settlement of migrants in the host country. It is considered to be part of human capital which immigrants transfer from their country of origin, however, it is not always transferable to the host country labour market. As it was found by Chiswick (1978) often immigrants' skills have limited use in the country of destination, which put immigrants in disadvantage positions. Moreover, language proficiency requires investing a lot of time and other inputs (Dustmann, 1999). Chiswick and Miller (2001) in their research about male immigrants in Canada who came from a back- 
ground with languages other than the primary or dominant languages of destination created model of language attainment based on the assumption that language skills are a form of investment in human capital. According to it immigrants who do not have proficiency in the destination language have to make additional investments in acquiring the dominant language of host country. This study reported that language proficiency may predict not only socioeconomic status but also the extent of integration into the social, political, cultural, and economic life of the majority population in the host country. Thus, it can be expected that:

Hypothesis 1. Higher language proficiency is positively associated with life satisfaction of immigrants.

Labour market integration is another important aspect of immigrants' life satisfaction. Labour market integration can be measured in a variety of ways. One of the main indicators that are available for estimation labour market outcomes are labour force and work status. There are two main groups: people in labour force and people who are not in the labour force. There are number of aspects which can prevent successful integration of migrant to the labour market.

Research that was conducted in 18 countries found that a number of factors which influence on labour market participation of migrants such as language acquisition, countries of origin and destination, discrimination against a particular ethnic group, size of immigrant community (Van Tubergen et al., 2004). It was also found that, previous contact with the language of the receiving only had a positive effect in the employment opportunities of the men. However, these findings are contradictory to the common findings from studies which were conducted earlier by Borjas (1987) or Jasso and Rosenzweig (1990), according to which this factor has significantly positive effect on employment status.

In study undertaken by Kalter (2002) the transition from blue-collar to white-collar positions is analyzed using the SOEP data (2002) and the effect of linguistic skills on occupational mobility was examined. The results of this study reported that in addition to the standard variables of the human capital theory, the proficiency in language of the receiving country alone increases opportunities for better employment positions and higher income. At the same time, it revealed that ethnic networks and the language of origin do not have an independent influence on the improvement of occupational status and that the ethnic disadvantages of the Turks in Germany that remain following the control of education become statistically insignificant with the linguistic and network variables (Kalter, 2005). According to the findings, low position of the most immigrants, even after controlling for education, is associated with their lower level of language proficiency and as a result lack in inter-ethnic networks.

Labour market integration has been focus of so many studies also due to frequent cases of discrimination which a lot if immigrants face. Study of immigrant employment in Canada, New Zealand, Switzerland and the United States reported that there was some preoccupation against non-white immigrants in New Zealand with statistically significant nonwhite employment deficiency (Khan, 2004). In addition, experiencing barriers to participation in the labour market may have substantial effect impacts on immigrants' well-being. Research about work experience of Indian women in New Zealand revealed that work discrimination is 
associated with psychological and emotional problems (Pio, 2005). It was found in large body of studies that perceived employment and income opportunities are one of the crucial factor of intention to migrate (Kennan et al., 2011). It can be expected that:

Hypothesis 2. Labour market integration positively mediate relationship between language proficiency and life satisfaction

It was previously found that inter-ethnic contacts of immigrants with native population may positively contribute to language proficiency of the host country (Chiswick and Miller 2001). However, it can be expected that there is also reverse relation when language proficiency predicts contact with natives. It was recently found in longitudinal study in the Netherlands that such immigrants' characteristics as education and proficiency in host country language have significant role in establishing contacts with natives (Martinović et al., 2009). In this study it is expected that:

Hypothesis 3. Inter-ethnic contacts positively mediate relationship between language proficiency and life satisfaction

The focus of this study is two largest immigrant groups in the Netherlands: Turks and Moroccans. It was found in recent comparative study about labour market integration of immigrants in France, Germany and the United Kingdom that there are significant differences between first and subsequent generations of immigrants in terms of education, earnings, and employment. Thus, it was hypothesized that:

Hypothesis 4. Second generation of Turks and Moroccans have higher level of language proficiency, labour market integration and more frequent inter-ethnic contact which result in higher level of life satisfaction.

\section{Data and method}

For the analysis data from the first wave of the Netherlands Longitudinal Lifecourse Study (NELLS) conducted between 2008 and 2010 was used. The main purpose of that survey was to collect longitudinal panel information for sociological studies. Respondents were selected by a two-stage stratified sampling. For the first stage 35 municipalities were quasi-random selected by region and urbanization and for the second stage random selection based on age and country of origin of the respondents and their parents was applied. First wave of survey included two parts: face-to-face interview and self-completion questionnaire. The aim of face-to-face interview was to gain information about socio-economic and sociodemographic background of the respondent. The self-completion questionnaire was designed to provide information on the variables of interest: attitudes, values and norms, ability, and social integration variables.

The key specifics of that survey is oversample of two largest ethnic minority groups in the Netherlands: Turks and Moroccans. Thus, data can be useful for investigation attitudes, norms and values among immigrants.

For the purpose of this study only participants with Turkish and Moroccans background are examined, thereby native population and other non-western immigrants were excluded from the analysis. Participants who did not complete ques- 
tionnaire were also excluded. The final sample was 2012. The age of participants ranged between 15 and $49(\mathrm{M}=30.95, \mathrm{SE}=8.97)$ and it was equally gender distributed with $52.9 \%$ of females and $47.1 \%$ of males.

Life satisfaction was measured with four items: "My life is for most parts ideal" (1), "My living conditions are excellent" (2), "Overall, I am content with my life" (3), "The most important things I expect from life I achieved so far" (4). All answers were rated on a 5-point bipolar scale ranging from fully agree (1) to fully disagree (5). Scoring means were reversed for all items that the numerical scoring scale runs in the opposite direction, thus higher scores indicate more life satisfaction. Analysis of reliability indicated high Cronbach's Alpha $=.867$.

Language proficiency was assessed with four items: "can understand Dutch", "Can speak Dutch", "Can read Dutch", "Can write Dutch". Answers were rated on a 5-point bipolar scale ranging from very good (1) to not at all (5). Scoring means were reversed for all items that the numerical scoring scale runs in the opposite direction and variable language proficiency was computed using mean of these four recorded items. Higher scores indicate higher language proficiency. Analysis of reliability indicated Cronbach's Alpha $=.964$.

Inter-ethnic contacts were measured with tree items: "Contact in neighborhood", "Contact at work/school", "Contact in leisure clubs". Answers were rated on a 7-point Likert scale ranging from every day (1) to never (7). Scoring means were reversed for all items that the numerical scoring scale runs in the opposite direction. Higher scores indicate more frequent inter-ethnic contacts. Analysis of reliability indicated low Cronbach's Alpha $=.474$, however variable inter-ethnic contacts was computed using mean of these three recorded items due to the fact that these items do not depend on each other.

Labour market integration was treated as binary variable $(1=$ integrated in the labour market and $0=$ not integrated) constructed with following item: "What did you do right after leaving fulltime education?", "Ever had a job?", "Have you always worked since your first job?", "Do you have currently paid work?".

As control variables the dummy variable female (male $=0$ and female $=1$ ) and continuous variable age were added in the analyses.

For the analysis the IBM SPSS Statistic 22 software and Mplus (version 7) were used. At the first step all variables were constructed using SPSS, at the second step factor analysis for latent variable life satisfaction and main analysis to investigate the indirect effect of language proficiency on life satisfaction through proposed mediators labour market integration and inter-ethnic contacts were performed using structural equation modeling method in Mplus. The percentage of missing values did not exceed $1 \%$ for all the variable.

\section{Results}

The mean score for the language proficiency was $4.21(\mathrm{SD}=.96)$. This indicated good language knowledge among Turkish and Moroccans immigrants with score significantly higher mid-point of the scale, $t(1959)=193.36, p<.001$. Overall, $46 \%$ of the participants reported very good language proficiency, $24 \%$ of the participants scored a good knowledge, $16 \%$ indicated sufficient language proficiency and $14 \%$ claimed to have bad language knowledge or not have it at all. 
The mean score inter-ethnic contacts was $4.96(\mathrm{SD}=1.42)$ which indicated high frequency of contacts with native population among immigrants and it was significantly higher than scale middle point, $t(1828)=149.70, p<.001$.

The mean score of life satisfaction which was constructed from the four items for descriptive analysis in SPSS was $3.63(\mathrm{SD}=0.75)$. It indicated that life satisfaction among Turks and Moroccans is higher mid-point of the scales, $t(1997)=216.32, p<.001$.

Table 1

Mean and standard deviation for all variables

\begin{tabular}{lcccc}
\hline & M & SD & N & Range \\
\hline Life satisfaction & 3.633 & 0.751 & 1998 & $1-5$ \\
Language proficiency & 4.205 & 0.963 & 1960 & $1-5$ \\
Inter-ethnic contacts & 4.964 & 1.418 & 1829 & $1-7$ \\
Labour market integration & 0.612 & 0.487 & 2012 & $0 / 1$ \\
Male & 0.471 & 0.499 & 2301 & $0 / 1$ \\
Age & 30.948 & 8.969 & 2301 & $14-49$ \\
First generation & 0.638 & 0.481 & 2012 & $0 / 1$ \\
Education & 2.858 & 1.587 & 2011 & $1-6$ \\
\hline
\end{tabular}

Dependent and independent variables as well as two mediators are significantly correlated with each other in the predicted direction. Life satisfaction is positively correlated with main predictor variable language proficiency $(r=.12)$. It is also positively associated with both mediators: inter-ethnic contacts $(r=.23)$ and labour market integration $(r=.06)$. At the same time life satisfaction has significant negative correlation with all control variables (gender, age, first generation) except education which is not significantly correlated with outcome variable.

Analysis of correlation indicated that language proficiency had positive correlation with inter-ethnic contacts $(r=.27)$ and labour market integration $(r=.16)$, both correlation were significant. Furthermore, language proficiency is strongly negatively correlated with control variables age and first generation. At the same time these control variables are highly positively correlated with each other, which indicates that first generation of immigrants, which is represented by older population are more likely to have weak language proficiency.

Both mediators: inter-ethnic contacts and labour market integration are positively correlated with each other. Additionally, inter-ethnic contacts is negatively related to age and first generation which means that younger people and second generation immigrants tend to have more contacts with native Dutch population. It was also found that inter-ethnic contacts are more common among male and higher educated immigrants.

Labour market integration is positively correlated with all control variables; however, there is no significant relation between labour market integration and being first generation immigrant.

Confirmatory factor analysis (CFA) was conducted in Mplus in order to investigate whether four items used to measure life satisfaction are consistent with 
one latent factor. The first model did not fit the data well with $\chi^{2}(2)=22.11$, $p<.001)$; CFI $=.99$; TLI $=99$; and $\mathrm{RMSEA}=.07$ and $90 \% \mathrm{CI}=0.046-0.099$. To improve model fit two items were allowed to covary ('My life is for most parts ideal' and 'Overall, I am content with my life'). After that improvement satisfactory model fit was obtained which was indicated by $\left.\chi^{2}(1)=4.08, p<.05\right)$; $\mathrm{CFI}=.99$; $\mathrm{TLI}=99$; and $\mathrm{RMSEA}=.04$ and $90 \% \mathrm{CI}=0.006-0.082$. All the factor loadings were statistically significant $(p<.001)$ and the standardized factor loadings were between .69 and .86 .

In order to investigate how language proficiency effects on life satisfaction among Turks and Moroccans, structural equation model was employed in Mplus with life satisfaction as dependent variable, language proficiency as main predictor and two mediators: labour market integration and inter-ethnic contacts. Indirect effect of predictor on the dependent variable was also included in the Mplus estimation. After running the model fit was not acceptable with insignificant Chi-square $\left.: \chi^{2}(22)=31.17, p>.05\right)$; CFI $=.99$; TLI $=99$; and RMSEA $=.02$ and $90 \% \mathrm{CI}=0.000-0.026$. It was indicated that control variable first generation does not have significant effect neither on dependent variable nor on two mediators, so it was decided to exclude it from the model and test difference between first and second generation in a separate analysis.

After running the model again Mplus indicated good model fit: $\chi^{2}(4)=34.88$, $p<.05)$; CFI $=.99$; TLI $=99$; and RMSEA $=.02$ and $90 \% \mathrm{CI}=0.009-0.031$, thus there was no need in model modification.

Table 2

Standardized model coefficients

\begin{tabular}{lccccccccccc}
\hline & \multicolumn{3}{c}{ Inter-ethnic contacts } & \multicolumn{3}{c}{$\begin{array}{c}\text { Labour market } \\
\text { integration }\end{array}$} & \multicolumn{4}{c}{ Life satisfaction } \\
Variables & $\begin{array}{c}\text { Coeffi- } \\
\text { cient }\end{array}$ & SE & P & $\begin{array}{c}\text { Coeffi- } \\
\text { cient }\end{array}$ & SE & $P$ & $\begin{array}{c}\text { Coeffi- } \\
\text { cient }\end{array}$ & SE & $P$ \\
Language proficiency & 0,198 & 0,024 & 0,000 & 0,214 & 0,030 & 0,000 & 0,020 & 0,027 & 0,439 \\
Inter-ethnic contacts & & & & & & & & & 0,205 & 0,026 & 0,000 \\
Labour market integration & & & & & & & & 0,077 & 0,025 & 0,024 \\
Male & 0,153 & 0,022 & 0,000 & 0,228 & 0,021 & 0,000 & $-0,097$ & 0,024 & 0,000 \\
Age & $-0,158$ & 0,024 & 0,000 & 0,252 & 0,027 & 0,000 & $-0,123$ & 0,028 & 0,000 \\
Education & 0,105 & 0,024 & 0,000 & 0,192 & 0,026 & 0,000 & $-0,041$ & 0,025 & 0,103 \\
\hline
\end{tabular}

Table 2 presents standardized model coefficients. Language proficiency turned out not to significantly predict life satisfaction of immigrants in the Netherlands $(b=.02, \mathrm{SE}=.03, p>.05)$. However, the rest of variables in the model including all control variables showed significant impact in explaining life satisfaction. The relation between language proficiency and life satisfaction was found to be significantly mediated by inter-ethnic contact $(b=.04, \mathrm{SE}=.01, p<.001)$. Inter-ethnic contacts were linked with higher language proficiency $(b=.20, \mathrm{SE}=.02, p<.001)$ and furthermore life satisfaction had significant direct effect of inter-ethnic contacts $(b=.21, \mathrm{SE}=.03, p<.001)$. The estimated indirect effect through second mediator labour market integration was also significant $(b=.02, \mathrm{SE}=.01, p<.05)$ with significant association between language proficiency and labour market inte- 
gration $(b=.21, \mathrm{SE}=.03, p<.001)$ and between labour market integration and life satisfaction $(b=.08, \mathrm{SE}=.03, p<.05)$. Control variable male was significantly related to life satisfaction $(b=-.10, \mathrm{SE}=.02, p<.001)$ as well as age $(b=-.12$, $\mathrm{SE}=.03, \mathrm{p}<.001)$, however education did not have significant effect on life satisfaction $(b=-.04, \mathrm{SE}=.03, p>.05)$. Finally, all control variables were significantly related to both mediators.

To test hypothesis about first and second generation the structural model for group comparison was run in Mplus. The model fit was good $\chi^{2}(43)=76.37$, $p>.05)$; CFI $=.99$; TLI $=99$; and $\mathrm{RMSEA}=.03$ and $90 \% \mathrm{CI}=0.017-0.038$. The Wald test for differences across two groups was not significant $\left(\chi^{2}(6)=12.39\right.$, $p>.05)$, revealing that path coefficients do not significantly differ from each other between first and second generation.

\section{Conclusion}

The present study investigates the effect of language proficiency on life satisfaction of Turks and Moroccans immigrants in the Netherlands. It was hypothesized that this relationship would be mediated by labour market integration and inter-ethnic contacts with native population. The aim of current study was to test language proficiency as main predictor of life satisfaction. Results of this study were consistent with hypotheses that higher language proficiency is positively associated with life satisfaction and that relationship was positively mediated by two mediators. However, the analysis indicated that the expected direct effect was not significant, so Hypothesis 1 was rejected. Thus, it was concluded that language proficiency itself is not related to life satisfaction, nevertheless it increases both frequency of contacts with natives (Hypothesis 2) and labour market integration (Hypothesis 3).

Socio-demographic characteristics such as age, education and gender were also included in the analyses. All of them had significant impact to the model that was in line with previous researches (Martinović, 2013; Kalmijn, Van Tubergen, 2006). Male immigrants are more likely to have inter-ethnic contacts and be integrated in the labour market, at the same time, Turks and Moroccans men tend to be less satisfied with their life, which lays in the same vain with findings of FuglMeyer (2009). Age is negatively associated with inter-ethnic contacts and life satisfaction but has positive relation with labour market integration. As it was recently found education plays a big role in establishing inter-ethnic contacts: highereducated immigrants have more contacts with natives (Martinović, 2013), thus results of current study were in line with these findings. Education had significant positive effect on both mediators; however, it was negatively associated with life satisfaction can be explained with the fact that highly skilled migrants are offered jobs that did not match their skills as it was previously revealed on the example of immigrants from the former Soviet Union in Israel (Eckstein, Weiss, 2002).

It was also hypothesized that second generation of immigrants will demonstrate higher level of language proficiency, labour market integration, inter-ethnic contacts and life satisfaction, however no significant effect related to second generation was found, which is opposite to previous studies (Crul, Vermeulen, 2003). 
However, this study as well comprises several limitations. First of all, it can be assumed that for almost all second generation immigrants Dutch language is a first language, thus it may be problematic to make a conclusions about it impact taking into account that fact. Second, considering language proficiency and interethnic contacts raises question about causality of the relationship, since that relationship may work in both directions: inter-ethnic contacts can be a predictor of better language proficiency. Third, it is important to consider that not all contacts with natives are associated with higher life satisfaction of immigrants. Negative social contact can strengthen perceived discrimination and decrease life satisfaction (Barlow et al., 2012).

In conclusion, this research shows that labour market integration and inter-ethnic contacts play significant role in formation of life satisfaction of immigrants in the Netherlands. For future research we would propose to divide negative and positive contact to test the separate effect on life satisfaction and would expect that effect of negative contacts will be negatively associated with life satisfaction. In addition, it can be suggested to exclude from the analysis second generation immigrants. Moreover, it would be relevant to test a model separately for men and women to investigate if there are differences in path coefficients for these two groups.

\section{References}

Algan, Y., Dustmann, C., Glitz, A., \& Manning, A. (2010). The Economic Situation of First and Second-Generation Immigrants in France, Germany and the United Kingdom. The Economic Journal, 120(542), F4-F30.

Arrindell, W.A., Heesink, J., \& Feij, J.A. (1999). The satisfaction with life scale (SWLS): Appraisal with 1700 healthy young adults in The Netherlands. Personality and individual differences, 26(5), 815-826.

Barlow, F.K., Paolini, S., Pedersen, A., Hornsey, M.J., Radke, H.R., Harwood, J., ... \& Sibley, C.G. (2012). The contact caveat negative contact predicts increased prejudice more than positive contact predicts reduced prejudice. Personality and Social Psychology Bulletin, $38(12), 1629-1643$.

Bevelander, P. (2000). Immigrant employment integration and structural change in Sweden, 1970-1995 (vol. 15). Lund University.

Bjørnskov, C., Dreher, A., \& Fischer, J.A. (2008). Cross-country determinants of life satisfaction: Exploring different determinants across groups in society. Social Choice and Welfare, 30(1), 119-173.

Bleakley, H., \& Chin, A. (2004). Language skills and earnings: Evidence from childhood immigrants. Review of Economics and Statistics, 86(2), 481-496.

Böhnke, P. (2008). Does society matter? Life satisfaction in the enlarged Europe. Social Indicators Research, 87(2), 189-210.

Bonini, A.N. (2008). Cross-national variation in individual life satisfaction: Effects of national wealth, human development, and environmental conditions. Social Indicators Research, 87(2), 223-236.

Borjas, G.J. (1987). Self-selection and the earnings of immigrants. American Economic Review, 77(4), 531-553.

Chiswick, B.R., \& Miller, P.W. (2001). A model of destination-language acquisition: Application to male immigrants in Canada. Demography, 38(3), 391-409.

Christopher, K.A., \& Kulig, J.C. (2000). Determinants of psychological well-being in Irish immigrants. Western Journal of Nursing Research, 22(2), 123-143. 
Crul, M., \& Vermeulen, H. (2003). The second generation in Europe. International migration review, 37(4), 965-986.

Delander, L., Hammarstedt, M., Månsson, J., \& Nyberg, E. (2005). Integration of immigrants: the role of language proficiency and experience. Evaluation Review, 29(1), 24-41.

Diener, E.D., Emmons, R.A., Larsen, R.J., \& Griffin, S. (1985). The satisfaction with life scale. Journal of personality assessment, 49(1), 71-75.

Diwan, S. (2008). Limited English proficiency, social network characteristics, and depressive symptoms among older immigrants. The Journals of Gerontology Series B: Psychological Sciences and Social Sciences, 63(3), S184-S191.

Eckstein, Z., \& Weiss, Y. (2002). The integration of immigrants from the former Soviet Union in the Israeli labor market. The Israeli Economy, 1985-1998: From Government Intervention to Market Economics, 349-377.

Ersanilli, E., \& Koopmans, R. (2010). Rewarding integration? Citizenship regulations and the socio-cultural integration of immigrants in the Netherlands, France and Germany. Journal of Ethnic and Migration Studies, 36(5), 773-791.

Esser, H. (2006). Migration, language and integration. WZB.

Fugl-Meyer, A.R., Melin, R., \& Fugl-Meyer, K.S. (2002). Life satisfaction in 18-to 64-yearold Swedes: in relation to gender, age, partner and immigrant status. Journal of Rehabilitation Medicine, 34(5), 239-246.

Hamberger, J., \& Hewstone, M. (1997). Inter-ethnic contact as a predictor of blatant and subtle prejudice: Tests of a model in four West European nations. British Journal of Social Psychology, 36(2), 173-190.

Helliwell, J.F. (2003). How's life? Combining individual and national variables to explain subjective well-being. Economic Modelling, 20(2), 331-360.

Hiebert, D. (2009). The economic integration of immigrants in metropolitan Vancouver. IRPP.

Hong, S.M., Bianca, M.A., Bianca, M.R., \& Bollington, J. (1993). Self-esteem: the effects of life-satisfaction, sex, and age. Psychological Reports, 72(1), 95-101.

Jasinskaja-Lahti, I., Liebkind, K., Jaakkola, M., \& Reuter, A. (2006). Perceived discrimination, social support networks, and psychological well-being among three immigrant groups. Journal of Cross-Cultural Psychology, 37(3), 293-311.

Jasso, G., \& Rosenzweig, M.R. (1990). English language proficiency and the locational choices of immigrants. In The new chosen people: immigrants in the United States (pp. 308-337). New York, Russell Sage Foundation.

Kalmijn, M., \& Van Tubergen, F. (2006). Ethnic intermarriage in the Netherlands: Confirmations and refutations of accepted insights. European Journal of Population/Revue Européenne de Démographie, 22(4), 371-397.

Kalter, F., \& Granato, N. (2002). Ethnic minorities' education and occupational attainment: The case of Germany. Mannheim, MZES.

Khan, L. (2004) Immigration, skills and the labor market: international evidence. Journal of Population Economics, 17(3), 501-535.

Li, P.S. (2003). Deconstructing Canada's discourse of immigrant integration. Journal of International Migration and Integration/Revue de l'Integration et de la Migration Internationale, 4(3), 315-333.

Martinović, B. (2013). The inter-ethnic contacts of immigrants and natives in the Netherlands: A two-sided perspective. Journal of Ethnic and Migration Studies, 39(1), 69-85.

Martinović, B., Van Tubergen, F., \& Maas, I. (2009). Dynamics of interethnic contact: A panel study of immigrants in the Netherlands. European Sociological Review, 25(3), 303-318.

Pio, E. (2005) Standing in the foyer: work experiences of Indian women migrants in New Zealand. Equal Opportunities International, 24(1), 58-76

Remennick, L. (2004). Language acquisition, ethnicity and social integration among former Soviet immigrants of the 1990s in Israel. Ethnic and Racial Studies, 27(3), 431-454.

Sachs, J. (2003). Validation of the satisfaction with life scale in a sample of Hong Kong university students. Psychologia, 46(4), 225-234. 
Safi, M. (2010). Immigrants' life satisfaction in Europe: Between assimilation and discrimination. European Sociological Review, 26(2), 159-176.

Van Tubergen F., Mass I., and Flap H. (2004). The economic incorporation of immigrants in 18 Western societies: origin, destination and community effects. American Sociological Review, 69(5), 704-728.

Verkuyten, M. (1986). The impact of ethnic and sex differences on happiness among adolescents in the Netherlands. The Journal of social psychology, 126(2), 259-260.

Verkuyten, M., \& Thijs, J. (2013). Multicultural education and inter-ethnic attitudes. European Psychologist,18(3), 179.

Wagner, U., Van Dick, R., Pettigrew, T.F., \& Christ, O. (2003). Ethnic prejudice in East and West Germany: The explanatory power of intergroup contact. Group Processes \& Intergroup Relations, 6(1), 22-36.

Article history:

Received: 29 March 2019

Revised: 26 April 2019

Accepted: 22 May 2019

\title{
For citation:
}

Pletneva Iu.E. (2019). The role of labour market integration, language proficiency and inter-ethnic contacts in shaping life satisfaction among immigrants in the Netherlands. RUDN Journal of Economics, 27(2), 326-337. http://dx.doi.org/10.22363/2313-2329-201927-2-326-337

\section{Bio note:}

Iuliia E. Pletneva - Junior Researcher, the Institute of Socio-Political Research under the Russian Academy of Sciences (ISPR RAS). E-mail: julpletneva@yandex.ru

\section{Роль интеграции на рынке труда, владения языком и межэтнических контактов в формировании удовлетворенности жизнью среди иммигрантов в Нидерландах}

\author{
Ю.Э. Плетнева \\ Институт социально-политических исследований РАН \\ Российская Федерация, 119333, Москва, ул. Фотиевой, д. 6, корп. 1
}

Исследования показывают относительно низкую удовлетворенность жизнью среди иммигрантов и этнических меньшинств. В то же время доказано, что субъективное благополучие играет важную роль в процессе социальной интеграции иммигрантов. Настоящее исследование вносит вклад в существующую литературу, исследуя медиативную роль интеграции на рынке труда и межэтнических контактов в связи между знанием языка и удовлетворенностью жизнью среди первого и второго поколений турецких и марокканских иммигрантов в Нидерландах. На основе данных голландского лонгитюдного исследования жизненного курса (NELLS) был проведен анализ методом моделирования структурными уравнениями. Результаты показали, что хотя владение языком 
не оказывает прямого эффекта на повышение удовлетворенности жизнью среди иммигрантов, оно действительно имеет положительное воздействие через повышение трудовой интеграции и увеличение контактов с представителями этнического большинства.

Ключевые слова: миграция; удовлетворенность жизнью; социально-экономическая интеграция; владение языком; межэтнические контакты

\section{История статьи:}

Дата поступления в редакцию: 29 марта 2019

Дата проверки: 26 апреля 2019

Дата принятия к печати: 22 мая 2019

\section{Для цитирования:}

Pletneva Iu.E. The role of labour market integration, language proficiency and interethnic contacts in shaping life satisfaction among immigrants in the Netherlands (Роль интеграции на рынке труда, владения языком и межэтнических контактов в формировании удовлетворенности жизнью среди иммигрантов в Нидерландах) // Вестник Российского университета дружбы народов. Серия: Экономика. 2019. Т. 27. № 2. C. 326-337. http://dx.doi.org/10.22363/2313-2329-2019-27-2-326-337

\section{Сведения об авторе:}

Плетнева Юлия Эдуардовна - младший научный сотрудник Центра социальной демографии Института социально-политических исследований Российской академии наук. E-mail: julpletneva@yandex.ru 